\title{
USING DIGITAL LEARNING OBJECTS (DLOs) FOR STUDENTS' ACHIEVEMENT IN COMPUTER APPRECIATION STUDIES
}

\author{
Ibezim, N. E. (PhD), Onyia, A. A., and Nwangwu, E. C. \\ Department of Computer \& Robotics Education, \\ University of Nigeria, Nsukka, Nigeria
}

\begin{abstract}
The use of DLOs for students' achievement in Computer Appreciation Studies (CAS) was investigated. Quasi experimental design using non-equivalent groups (intact classes) was adopted. Five weeks of experiment guided by two research questions and null hypotheses were observed. Sixty-six students from two technical colleges participated. Data was collected using Computer Appreciation Achievement Test (CAAT) with a reliability index of 0.971. Data was analyzed using Mean and standard deviation, while the null hypotheses was tested using ANCOVA at 0.05 level of significance. The results showed significant increase in the scores of students taught CAS using DLOs irrespective of gender.
\end{abstract}

Keywords: Academic; Achievement; computer appreciation; Computer education; Delivery methods; Digital Learning Objects; Instruction; learning; Students; Teaching.

Cite this Article: Ibezim, N.E., Onyia, A.A., and Nwangwu, E.C, Using Digital Learning Objects (DLOs) for Students' Achievement in Computer Appreciation Studies. International Journal of Mechanical Engineering and Technology. 11(7), 2020, pp. 25-37.

https://iaeme.com/Home/issue/IJMET?Volume $=11 \&$ Issue $=7$

\section{INTRODUCTION}

Computer education is a study that encompasses the process of acquiring knowledge and skills in the application of computers for problem solving, and the development of competencies for transferring knowledge on the use of computers to learners. Computer education has also become one of the $21^{\text {st }}$ century occupation requirements. This can be attested to by the fact that there is no area in all works of life where computer knowledge is not a necessary tool. Furthermore, in the area of employment of labour, computer knowledge or compliance is a basic requirement, a key to modern education and thriving economies in the world (Ahmed, 2012; Cape Digital Foundation, 2018; Kajogbola, 2004; Oguz, 2011; Osaigbovo, n.d; Wang, 2013; World Economic Forum, 2013).

Consequently, to address this need of the society, computer education or studies have been introduced into schools as a legitimate subject offered from the lowest level of education to its zenith. Computer education is gaining some grounds in Africa as mobile technologies 
are now being used (Robson, 2014). However, this all-important basic skill for all works of life usually starts with computer appreciation studies. According to Kahn in ACM DL (2017), computer appreciation indicates the need for a broad scale education about computers. Computer appreciation therefore, is the ability to be conversant with the rudimentary issues about the computer including the basic application of computers for problem solving. This education called computer appreciation tends to be a very good start point for beginners at the lower educational levels to help learners gradually and appreciatively step into more complex studies on the computer (Ajani, Bakar \& Sidek, 2013). Being computer appreciated has made and is still making a living for many people across the globe today. However, if learners find the start point difficult to grasp and display low performance at that level, then moving into higher instruction may be counterproductive. It is a known fact that if students understand an initial lesson, subsequent lessons will be easily grasped (Pellegrino, Chudowsky \& Glaser, 2001; Findlay, 2014). Therefore, it is imperative that appropriate methodology be used for instructional delivery in order to ensure that learners attain initial necessary competencies. This is in tandem with the challenge of African educators in discovering innovative strategies for developing young learners in relevant training (Robson, 2014; Vidal-Castro, 2017).

To achieve relevant, good educational outcomes, teaching and learning environments need to be conducive and learner friendly. Utilization of good instructional facilities and services are basically a sure way of attaining this fit (Ganyaupfu, 2013; Olelewe \& Agomuo, 2016; Romero, Rosa, Corcoles \& Ponce, 2015). More so, the integration of instructional technology in the early classes is fundamental to basic computer skills and software programs (Heflin, Shewmaker \& Nguyen, 2017; Ndomi, 2005; Wentworth \& Middleton, 2014). Therefore, for a basic instruction like computer appreciation, it is important to identify instructional delivery strategies that will ensure formidable acquisition of basic computer literacy skills evidenced by improved academic performance that can carry an individual through life. It is also necessary to determine the implications of the application of such identified strategies on the performance of the learners as regards gender. This is important since previous studies have shown that gender can influence the results of applied instructional delivery methods (Adigun, Onihunwa, Irunokhai, Sada \& Adesina, 2015; Friedman, Losby, Boyko, Halton-Bauer \& Turnbull, 2011). An understanding of this will help instructors in the appropriate utilization of instructional delivery strategies in computer appreciation studies (CAS).

The prime aim of teaching is usually to produce obvious change in the learner (Ganyaupfu, 2013; Tebabal \& Kahssay, 2011). Teaching as a process results in needed variations in learners irrespective of gender, so as to attain precise results. This is necessary because literature has shown gender differences in computer education in terms of performance and attitudes (Kay, 2008; Leach \& Turner, 2015). The teaching of computer appreciation is projected to enable learners acquire basic knowledge and skills. Teaching computer studies in most technical colleges in Africa, especially in Nigeria, has been mainly done through the conventional (chalk and talk) method (CM), which is a one-way flow of information. Technical colleges are institutions that provide specialized training in a specific career or trade, including computer technology (Study.com, 2018). However, the learning resource that is usually presented in these technical colleges is only based on teacher notes and textbooks. There seem to be insufficient interaction with students and more emphasis has been given on theory without much practical activities. Failure of the students to thrive at their own pace and insufficient learner engagement are some of the drawbacks of this type of learning (Ayeni, 2011; Cape Digital Foundation, 2018; Romero et al., 2015). However, modern methods including the use of Digital Learning Objects (DLOs), seem to enable learner participation. 
Digital Learning Objects (DLOs) are web based modular resources that can be used and re-used to support learning activities (Maddaloni, 2013; Wiley, 2002). The best DLOs are often delivered through a variety of platforms rather than being tied to any one environment (iNACOL, 2013).

In addition, DLOs must be geared towards particular learning objectives such that they can be used in various settings (iNACOL, 2013; Vidal-Castro, 2017). The DLOs designed for this study targeted getting acquainted with the computer, its components and usage. The DLOs were mainly programmed simulation on computer appreciation content using authoring applications and tools. Most organizations that produce DLOs, depend on digital tools and accessories, and xml metadata, to provide a packaging for many uses. DLOs are usually provided for learners through various digital media instead of being restricted to a particular delivery medium. This is possible because the objects are usually designed for value, compactness and usability among technologies. This also increases the level of sharing them and proficiency (E-Learning Faculty Modules, 2016). More so, DLOs are effectively utilized in physical, simulated or blended learning platforms. In any platform, electronic assessment tools can be used as feedback for learners that need to be assigned specific DLOs (Cotton,2001; Jeno, Grytnes \& Vandvik, 2017; Kay \& Knaack, 2008; Ng’ambi, Brown, Bozalek, Gachago \& Wood, 2016).

The social learning theory holds that individuals learn through observation, imitation, and modelling; and that individuals reenact behaviors they have observed directly or seen in the media (Bandura, 1989; Gilbert, 2019). This corroborates the integration of Digital Learning Objects in the teaching of computer appreciation, as learners irrespective of gender, are exposed to new concepts and studies by observing, reflecting, and in turn, exhibit or demonstrate traits learnt. Similarly, self-determination theory posits that individuals are motivated when their innate needs for autonomy, connection and competence are fulfilled (Ryan and Deci, 2000; Cherry, 2019). In the context of being computer appreciated, these innate interests motivate learners for better academic achievement, in the sense that the computer being a tool used in all facets of life, there may be this drive, in individuals, to get to know how to use this tool (autonomy). Again, there may also be this push to relate with other individuals or scenarios (like the use of DLOs) to be computer appreciated (Connection). In consolidation, there may also be this desire to master the skills to ensure effective use of the tool (Competence).

However, investigation into the performance pattern of students in the results of the National Business and Technical Examination Board (NABTEB) of Nigeria, from 2010 to 2014 showed that students' performance in computer studies was very poor. One of the students' weaknesses identified by the Board was inadequate exposure to learning activities (Chief Examiner's Report, 2010 to 2014 in Okyumen \& Gbodi, 2015). Nwoji (2003) implicated the shortcomings of the $\mathrm{CM}$ in the poor performances of students in computer studies at the School Certificate Examination. Therefore, suitable strategies should be applied to ensure proper knowledge transfer and expected learning outcomes, thus, the use of DLOs in CAS to determine its effect on students' achievement. To address this issue, two research questions were formulated to guide the study:

- What are the effects of DLOs on the academic achievement of students in CAS?

- What are the effects of DLOs on students' academic achievement in CAS as regards gender? 


\section{Hypotheses}

The following hypotheses tested at 0.05 level of significance, guided the study:

Ho1: No significant difference exists in the mean scores of students taught CAS using DLOs and those taught with the conventional method (CM).

$\mathrm{Ho}_{2}$ : No significant difference exists in the mean scores of male and female students taught CAS using DLOs.

\section{MATERIALS AND METHODS}

\subsection{Design}

The research design used in the study was Quasi experimental. According to Dimsdale and Kutner (2004), quasi experimental design is used if random assignment of variables is not practical, or even possible. Quasi experiment shares similarities with the traditional randomized experiment in that both are involved in the use of independent variable, but differ specifically in its lack of element of random assignment to treatment. (Cohen, 2007; White \& Sabarwal, 2014).

The adopted research design was considered suitable because intact classes were used to prevent the disturbance of normal activities of the schools involved in the study. Two different teaching methods (DLOs and CM) were assigned to two classes to determine their effects in achievement of the students in CAS. Quasi-experimental design was effective for this study because it involved pre-test on Computer Appreciation Achievement Test (CAAT) for both classes before any treatment was given, then post-test, conducted, after the actual teaching process took place.

\subsection{Area of the Study}

The area of the study was Enugu State, Nigeria. Enugu State as an educationally advantaged State, houses many schools including technical colleges where students are equipped with skills in diverse technologies. Furthermore, technical colleges in Enugu State offer CAS as an integral part of the computer studies curriculum.

\subsection{Participants}

The participants in this study consisted of 896 Junior Secondary School one (JSS 1) students in the 2015/2016 academic session from the 15 technical colleges in Enugu State which offer computer studies. A sample size of 66 students were selected from two technical colleges using multistage sampling technique. At the first stage, three (3) schools which had well equipped computer laboratories and up to four(4) computer studies teachers were purposively selected. Random sampling technique was used in the second stage to select two schools for the experimental and control groups. In the third stage, one JSS1 class each was selected from the two schools, having 34 and 32 students for the experimental and control groups respectively. The ages of the participants were between $10-12$ years.

\subsection{Instrument}

The Computer Appreciation Achievement Test (CAAT) was developed by the researchers from the National Educational Research and Development Council (NERDC) curriculum content for computer studies. CAAT, a 50-item multiple choice test, was administered as pretest and post-test to determine students' achievement in CAS. The items were developed based on the six levels of Blooms Taxonomy of cognitive domain. In developing the test items, the researchers prepared a table of specifications that guided the development. 


\subsection{Validation}

The instrument (CAAT) was subjected to face and content validations by three experts. According to Gall, Gall and Borg (2007), face validation is an independent examination of test items to decide if they cover the content that the test is meant to measure; while, content validation, on the other hand, means systematic evidence produced by experts who outline the exact content that the test is expected to denote, and determine how well the content area is represented in the test items. Construct validity was further conducted to establish the convergent and discriminant validity of the instrument. Convergent validity denotes the degree to which a test measures the same thing as other tests that measure the same construct, while discriminant validity shows the extent a test does not measure constructs it should not measure (Thoma, Cook, Mcgrew, King, Pulsipher, Yep et al 2018). To achieve this, the instrument was administered to 40 JSS 2 students who have undergone the Computer appreciation class, in a technical college not used in the study, and scores were obtained. A Structural Equation Model was then developed using Analysis of Moment Structures (AMOS) software showing the correlations existing among the latent variables (constructs) that made up the test questions (indicator variables). The average of the sum of the squared standardized loadings for each of the variables - Software questions-SQ (0.60), Hardware questions - HQ (1.20), and Computer Appreciation Knowledge - CAK (0.60), were greater than 0.05 demonstrating convergent validity, while the discriminant values $-0.66,1.10$, and 0.80 respectively, yielded low correlation values (SQ <--> HQ - 0.22; SQ <--> CAK - 0.13; $\mathrm{HQ}<-->\mathrm{CAK}-0.80$ ), providing evidence of discriminant validity.

\subsection{Reliability}

The reliability of CAAT was determined using Kuder-Richardson K-R 20. The CAAT was administered on an intact class of 40 JSS 2 students who have been taught computer appreciation with the same curriculum, in a related Technical College. The assumption for the reliability test was that no equal difficulty levels existed among all the items in the scale, and the test yielded a reliability index of 0.971 .

\subsection{Experimental Procedure/Administration of the Instrument}

The quasi experimental study was carried out during the usual school lesson period and time table for JSS 1, with permission from the school authorities and subject heads. The study involved two technical colleges, one as the experimental group (EG), taught using DLOs and the other as the control group (CG), taught without DLOs.

Both groups were given pretest before actual teaching commenced. During the lessons, the two groups used the same computer appreciation curriculum used for JSS 1 students across schools in the area of study. The control group used lesson plans in the conventional format, chalkboard, lesson notes, and chalk as learning resources, while the experimental group used DLOs lesson plan, desktop computers, DLOs and the projector as learning resources. The students' ages, duration of lesson, specific objectives of the lessons were considered in preparing the lesson plans. The regular teachers were used to avoid experimental bias, and the researchers briefed those that handled the EG on how to use DLOs to teach. Each student in the experimental class was provided with a desktop computer with installed DLOs on CAS designed by the researchers. At each lesson period, the students learned as they studied the DLOs addressing the topic of the day, and equally asked questions where confused or needed clarifications. The teachers stood in as facilitators to guide the learning process and address unclear issues. Each lesson period was for 40 minutes, and three lesson periods were held per week for five weeks, totaling 15 lesson periods. 
At the end of the experiment, the students in the two groups were given the post-test by the usual class teachers. The post-test and pre-test achievement questions were the same in content for both groups but answer options and questions were reshuffled. The answer scripts were marked using the marking scheme prepared by the researchers to get students' scores on achievement. Students' scores got from the two tests were used for further analysis. The analysis determined any significant achievement in the two groups.

\subsection{Data Collection}

The data collected for the study were the test scores got from the pre-test and post-test given to the students using CAAT.

\subsection{Data Analysis}

Data collected were analyzed using mean and analysis of covariance (ANCOVA). The mean score gains of each group were computed for answering the research questions. ANCOVA statistics was used to test the hypotheses. According to Gall et al. (2007), ANCOVA helps to decide if there exists a consistent difference between the experimental group pretest-posttest difference, and the control group pretest-posttest difference. ANCOVA also helps in regulating the errors of initial non-equivalence that usually emanate from the use of intact classes (Uzuagulu, 1998). For the hypotheses, any item whose significant value was less than the alpha value (0.05) indicates a significant difference in the responses and therefore the null hypothesis would not be upheld, while any item whose significant value was greater than or equal to the alpha value indicates no significant difference, therefore, the null hypothesis would be upheld.

\section{RESULTS AND DISCUSSION}

Results in Table 1 show that the achievement mean of the EG $\left(\bar{x}_{\mathrm{g}}=42.00, \mathrm{SD}_{\mathrm{g}}=4.08, \mathrm{n}=\right.$ 34) was significantly higher than that of the $\mathrm{CG}\left(\bar{x}_{\mathrm{g}}=11.81, \mathrm{SD}_{\mathrm{g}}=6.19, \mathrm{n}=32\right)$. This is an indication that the use of DLOs produced higher effect as regards the students' academic achievement in CAS than in the use of the conventional method.

Table 1 Mean and Standard deviation of students' academic achievement scores in the groups

\begin{tabular}{lcccccc}
\hline & \multicolumn{2}{c}{ Pretest } & \multicolumn{2}{c}{ Posttest } & \multicolumn{2}{c}{ Mean Gain } \\
\hline Instructional Mode & $\mathrm{N}$ & $\bar{x}$ & $\mathrm{SD}$ & $\bar{x}$ & $\mathrm{SD}$ & $\left(\bar{x}_{\mathrm{g}}\right)$ \\
DLOs & 34 & 27.32 & 8.90 & 69.32 & 12.98 & 42.00 \\
$\mathrm{CM}$ & 32 & 26.13 & 7.41 & 37.94 & 13.60 & 11.81 \\
\hline
\end{tabular}

Similarly, Table 2 showed that for the two groups, the F-calculated value was significant $\mathrm{F}(1,63)=89.688, \mathrm{p}<.05 ; 95 \% \mathrm{Cl}$. This indicates that there exists a significant difference in the scores of students taught CAS using DLOs and those taught with the CM. The partial eta squared value (0.60) confirms this, as it indicates a significant percentage variance of $60 \%$ in the dependent variable (CAS test scores), that can be explained by the independent variable (instructional mode). The null hypothesis $\left(\mathrm{Ho}_{1}\right)$ was therefore not upheld. 
Ibezim, N.E., Onyia, A.A., and Nwangwu, E.C

Table 2 Summary of ANCOVA Test of the mean scores of the groups on Students' Achievement in CAS

\begin{tabular}{lcccccc}
\hline \multicolumn{1}{c}{ Source } & $\begin{array}{c}\text { Type III Sum } \\
\text { of Squares }\end{array}$ & Df & Mean Square & F & Sig. & $\begin{array}{c}\text { Partial Eta } \\
\text { Squared }\end{array}$ \\
\hline Corrected Model & $16279.938^{\mathrm{a}}$ & 2 & 8139.969 & 45.542 & .000 & 0.770 \\
Intercept & 14416.517 & 1 & 14416.517 & 80.659 & .000 & 0.423 \\
Pretest & 40.997 & 1 & 40.997 & .229 & .634 & 0.321 \\
Method & 16030.372 & 1 & 16030.372 & 89.688 & .000 & 0.601 \\
Error & 11260.319 & 63 & 178.735 & & & \\
Total & 220753.000 & 66 & & & & \\
Corrected Total & 27540.258 & 65 & & & & \\
\hline
\end{tabular}

$\alpha=0.05$

Table 3 shows the effect of gender on students' achievement in CAS, in the two groups. The table showed that male students taught CAS using DLOs had $(\bar{x}=26.58, \mathrm{SD}=8.30)$ in the pretest, and $(\bar{x}=68.88, \mathrm{SD}=14.89)$ in the posttest, giving a mean gain of $\left(\bar{x}_{\mathrm{g}}=42.30\right)$. The female students taught CAS using DLOs, on the other hand, achieved $(\bar{x}=29.10, \mathrm{SD}=$ $10.46)$ in the pretest and $(\bar{x}=70.40, \mathrm{SD}=7.06)$ in the posttest, giving a mean gain of $\left(\bar{x}_{\mathrm{g}}=\right.$ 41.30). Furthermore, in the CM, male students had $(\bar{x}=26.25, \mathrm{SD}=7.57)$ in the pretest and $(\bar{x}=39.10, \mathrm{SD}=14.69)$ in the posttest, giving a mean gain of $\left(\bar{x}_{\mathrm{g}}=12.85\right)$. The female students on the other hand had $(\bar{x}=25.92, \mathrm{SD}=7.48)$ in the pretest and $(\bar{x}=36.00, \mathrm{SD}=$ $11.94)$ in the posttest, giving a mean gain of $\left(\bar{x}_{\mathrm{g}}=10.08\right)$. These results suggest that gender had no effect on the academic achievements of the students, as the mean gains of the male and female students are within the same range (42.30 and 41.30 respectively).

Table 3 Mean and Standard deviation of students' achievement scores in the groups as regards gender

\begin{tabular}{ccccccccc}
\hline $\begin{array}{c}\text { Instructional } \\
\text { Mode }\end{array}$ & Variable & Gender & $\mathbf{N}$ & $\overline{\mathbf{x}}$ & SD & $\overline{\mathbf{x}}$ & SD & $\begin{array}{c}\text { Mean } \\
\text { Gain }\left(\overline{\boldsymbol{x}}_{\mathbf{g}}\right)\end{array}$ \\
\hline \multirow{3}{*}{ DLOs } & \multirow{2}{*}{ Achievement } & Male & 24 & 26.58 & 8.30 & 68.88 & 14.89 & 42.30 \\
& & Female & 10 & 29.10 & 10.46 & 70.40 & 7.06 & 41.30 \\
& & Total & 34 & 27.32 & 8.90 & 69.32 & 12.98 & 42.00 \\
& & Male & 20 & 26.25 & 7.57 & 39.10 & 14.69 & 12.85 \\
CM & \multirow{2}{*}{ Achievement } & Female & 12 & 25.92 & 7.48 & 36.00 & 11.94 & 10.08 \\
& & Total & 32 & 26.13 & 7.41 & 37.94 & 13.61 & 11.81 \\
\hline
\end{tabular}

Table 4 shows the F-calculated values for the mean test scores in the two groups as regards gender $\mathrm{F}(1,65)=0.06 ; \mathrm{p}>0.05,95 \% \mathrm{Cl}$. This indicates that there was no significant difference as regards gender in the students' achievement in CAS. Furthermore, the table showed the interaction effect of the treatment and gender $\mathrm{F}(1,65)=0.37 ; \mathrm{p}>0.05$, indicating no significant interaction effect of the treatment and gender with respect to students' achievement in CAAT. The Partial Eta squared of 0.000 confirmed these results as it showed a non-significant percentage variance of $0 \%$ in the dependent variable (CAS test scores) that can be explained by the independent variable (gender). 
Table 4 Summary of ANCOVA Test for achievement in the groups and the treatment as regards gender

\begin{tabular}{lcccccc}
\hline \multicolumn{1}{c}{ Source } & $\begin{array}{c}\text { Type III Sum } \\
\text { of Squares }\end{array}$ & Df & Mean Square & F & $\begin{array}{c}\text { Sig. } \\
\text { Partial } \\
\text { Eta } \\
\text { Squared }\end{array}$ \\
\hline Corrected Model & $16362.288^{\mathrm{a}}$ & 4 & 4090.572 & 22.323 & .000 & 0.343 \\
Intercept & 13966.816 & 1 & 13966.816 & 76.219 & .000 & 0.427 \\
Pretest & 34.855 & 1 & 34.855 & .190 & .664 & 0.343 \\
Method & 14673.722 & 1 & 14673.722 & 80.077 & .000 & 0.010 \\
Gender & 11.375 & 1 & 11.375 & .062 & .804 & 0.000 \\
Method * Gender & 68.889 & 1 & 68.889 & .376 & .542 & 0.000 \\
Error & 11177.970 & 61 & 183.245 & & & \\
Total & 220753.000 & 66 & & & & \\
Corrected Total & 27540.258 & 65 & & & & \\
\hline
\end{tabular}

a R Squared $=.522($ Adjusted R Squared $=.512)$

$$
\alpha=\mathbf{0 . 0 5}
$$

\section{DISCUSSION}

The results of the study revealed that the effect of using DLOs and the CM in students' academic achievement in CAS was statistically significantly different. Data collected showed that the use of DLOs had higher effects on students' academic achievement in CAS than the use of the CM. This finding could be attributed to the assertions of Friedman et al. (2011); Reyna, Meier, Geronimo and Rodgers (2016); and Tanaka, Catalan, Zemiack, Pedro, Cogo and Silveira (2010), that technology integration in instruction delivery supports active engagement, frequent interaction and feedback. The results also strengthen the proposal made by Zimudzi (2012) on the use of DLOs for computer studies in schools, because technical and pedagogical usability criteria are considered during the development of DLOs. The study of Akpinar (2014) confirms this as the results showed that use of DLOs increases student academic achievement in different modes of learning. This increase in achievement further reaffirms earlier reports that the use of multimedia in instruction delivery is an effective means of reaching better results (Aloraini, 2012; Basogain, Olabe, Olabe \& Rico, 2018; Gibson, Ostashewski, Flintoff, Grant \& Kright, 2015; Olawojero, 2013). Recent studies had recommended that teachers should employ mobile application tools due to their positive impact on academic motivation and potential economic empowerment (Jeno et al, 2017; Kajogbola, 2004; Nguen, Rienties, Toetenel, Ferguson \& Whdelock, 2017; Robson, 2014).

Furthermore, Janson and Janson (2010), in corroboration, reported that the use of DLOs enables students to work hands-on with difficult content and concepts. The authors further asserted that DLOs enable students work at their pace and can give support learning tasks that provide immediate feedback on performance and learning in different helpful and engaging ways. Teachers also use DLOs in a variety of ways to meet curriculum needs and address differing learning abilities among their students. The study of Al-Hariri and Al-Hattami (2017), in support of this finding revealed that digital learning presents better positive effects on learning motivation and outcome than traditional teaching does. Harris, Al-Bataineh and Al-Bataineh (2016) had earlier stated that more technology exposure for students may be the catalyst needed for schools to help their students achieve at higher levels.

On a similar note, the ANCOVA results show that there exists no significant interaction effect between the treatment given and gender as regards the students' mean scores. This finding is supported by the study of Godpower-Echie and Ihenko (2017) which revealed that gender does not have a significant influence on academic achievement. Some other earlier studies have also suggested that gender has no effect on achievement with the use of mobile technology application (Hou \& Li, 2014; Jeno et al, 2017; Ng'ambi et al., 2016; Page, 2014). 
These findings substantiate the theory of social learning, in the sense that the higher academic achievement in favour of the learners' use of DLOs indicate that the students' interaction with the DLOs produced positive cognitive and learning abilities. Furthermore, the finding on gender not having any influence on the achievement of the students, supports the self-determination theory, in the sense that the innate drive in the students and the use of the competency induced DLOs in computer appreciation motivated the learners for higher results irrespective of gender. Jason and Jason (2010) had earlier stated that in using DLOs, learners use information communication technologies to build knowledge and to communicate with others for increased performance.

\section{CONCLUSION}

Computer appreciation, a fundamental aspect of Computer education requires a dependable instructional delivery strategy to ensure effective transfer of appropriate skills and improved academic performance of students especially at the early levels of education. This is important because skills acquired at this lower educational level will aid the students in their subsequent use of computer technology in academic and professional endeavors. Consequent on this, the study cashed in on the fact that effective technology integration deepens and enhances the learning process, especially in its support for active engagement, frequent interaction and feedback, to determine the effect of DLOs on the academic performance of students in CAS. The findings in this study showed that more effective learning in CAS takes place with the use of DLOs as teaching aids. The use of DLOs also increased the performance of the students in CAS more than the use of the conventional method. Similarly, teaching with DLOs increased the academic achievement of both male and female students in CAS.

The findings from this study suggest that the use of DLOs as an approach to individualizing instruction can offer a good hope for schools that are intently searching for ways of addressing individual needs of students or groups with similar needs. It is equally a known fact that the use of appropriate teaching approaches is an indicator of ideal results in education. Moreover, in teaching foundational subjects, it is expedient that appropriate teaching strategies are discovered and used for subsequent better results. This is the job this study has done with bias to computer appreciation, a foundation to the computing discipline. It is therefore imperative that proper planning and provision of necessary resources should be put in place to fully optimize the use of DLOs in teaching of computer studies. Teachers should also be willing to fully adopt their expected roles in the application of DLOs in the learning process.

In as much as this study cannot specifically state the degree of correctness of the results, it has some level of credibility as regards comparisons the study made in relation to other studies. Moreso, the restricted focus on computer appreciation and lack of comparative data on other computing education concepts is another limitation of this study. More research on this issue is encouraged, possibly not just in technical schools but other private and public schools.

\section{ACKNOWLEDGMENTS}

The researchers appreciate the Education Trust Fund (ETF) through the Science and Technology Education Post-Basic (STEP-B) Project which sponsored the development of the DLOs used in this study. The researchers are equally grateful to the administration of the technical colleges used for the study, for the enabling environment given. 


\section{REFERENCES}

[1] ACM, D. L. (2017). An appreciation of computer appreciation. Available at http://dl.acm.org/citation.cfm?id=806012. Accessed 16 January 2017.

[2] Adigun, J., Onihunwa, J., Irunokhai, E., Sada, Y. \& Adesina, O. (2015). Effect of Gender on students' academic performance in Computer Studies in secondary schools in New Bussa, Borgu Local Government of Niger State. Journal of Education and Practice, 6(33):1-7.

[3] Ahmed, S. O. (2012). Importance of Computer Education. Available at http://happymela.blogspot.com.ng/2012/11/essay-importance-of-computer education.html. Accessed 18 January 2017.

[4] Ajani, S. T., Bakar, B. A. \& Sidek, H. M. (2013). Appreciation of computer knowledge in the teaching and learning of Islamic Studies in Nigeria. American International Journal of Social Science, 2(2):56-66.

[5] Akpinar, Y. (2014). Different modes of digital learning object use in school setting: Do we design for individual or collaborative learning? International journal of Education and Development using information and Communication Technology (IJEICT), 10(3):87-95.

[6] Aloraini, S. (2012). The impact of using multimedia on students' academic achievement in the College of Education at King Saud University. Journal of King Saud University - Language and Translation, 24(2):75-82.

[7] Al-Hariri, M. T. \& Al-Hattami, A. A. (2017). Impact of students' use of technology on their learning achievements in physiology courses at the University of Dammam. Journal of Taibah University Medical Sciences, 12(1), 82-85.

[8] Ayeni, A. J. (2011). Teachers professional development and quality assurance in Nigerian Secondary Schools. World Journal of Education, 1(2):43-149.

[9] Bandura, A. (1989). Social cognitive theory. In R. Vasta (Ed.). Annals of child development. Vol 6. Six theories of child development, Greenwich, CT: JAI Press.

[10] Basogain, X., Olabe, M. A., Olabe, J. C. \& Rico, M. J. (2018). Computational thinking in preuniversity Blended Learning classrooms. Computers in human behavior, 80(March 2018):412-419. https://doi.org/10.1016/j.chb.2017.04.058

[11] Cape Digital Foundation (2018). How will education meet the rising demand for ICT skills in South Africa? Available at http://digitalfoundation.org.za/how-will-education-meet-risingdemand-ict-skills-south-africa/. Accessed 22 April 2019

[12] Cherry, K. (2019). Self-Determination Theory and Motivation. Available at https://www.verywellmind.com/what-is-self-determination-theory-2795387. Accessed 15 April 2020.

[13] Cohen, L. (2007). Research methods in education. New York: Routledge.

[14] Cotton, K. (2001). Computer assisted instruction. Portland, Sweden: North West Regional Educational laboratory. Available at http.//www.nwrel.org/scpd/sirs/5/cuio.html. Accessed 1 April 2016.

[15] Dimsdale, T. \& Kutner, M. (2004). Becoming an educated consumer of research. A quick look at basics of research methodologies and Design. Paper presented at the Meeting of the Minds Practitioner-Researcher Symposium, Washington, 33 December.

[16] E-Learning Faculty Modules (2016). Building Digital Learning Objects (DLOs). Available at http://elearningfacultymodules.org/index.php/Building_Digital_Learning_Objects _\%28DLOs\%29\#Extra_Resources. Accessed 19 January 2017. 
[17] Friedman, A. J., Losby. R., Boyko, S., Halton-Bauer, J. \& Turnbull, G. (2011). Effective teaching strategies and methods of delivery for patient education: A Systematic review and practice guideline recommendation. Journal of Cancer Education 26(1):12-21.

[18] Gall, M. D., Gall, J. P. \& Borg, W. R. (2007). Educational Research: An Introduction ( ${ }^{\text {th }}$ ed). USA, Pearson Education Inc.

[19] Ganyaupfu, E. M. (2013). Teaching methods and students' academic performance. International Journal of Humanities and Social Science Invention, 2(9):29-29.

[20] Gibson, D., Ostashewski, N., Flintoff, K., Grant, S. \& Kright, E. (2015). Digital badges in Education. Education and Information Technologies, 20(2):403-410.

[21] Gilbert, N. (2019). The 6 Social Work Theories that inform social work practice. Available at: https://www.noodle/article/the-6-social-work-theories-that-inform-social-work-practice. Accessed 9 April 2020.

[22] Harbinger Interactive Learning (2016). Digital Learning Objects (DLOs). Available at http://www.harbingerlearning.com/solutions-digital-learning-objects.html. Accessed 25 November 2016.

[23] Heflin, H., Shewmaker, J. \& Nguyen, J. (2017). Impact of Mobile technology on students' attitudes, engagement and learning. Computers \& Education, 107(2017):91-99.

[24] Hou, A. T. \& Li, M. C. (2014). Evaluating multiple aspects of a digital educational problemsolving based adventure game. Computers in Human Behaviour, 30(January):29-38.

[25] iNACOL (2013). iNACOL Blended and Online Learning Symposium. Available at https://concord.org/conferences/inacol-2013. Accessed 25 November 2016.

[26] Janson, A. and Janson, R. (2010). Integrating Digital Learning Objects in the Classroom: A Need for Educational Leadership. Available at http://citeseerx.ist.psu.edu/viewdoc/download?doi=10.1.1.186.4676\&rep=rep1\&type=pdf. Accessed 24 April 2020.

[27] Jeno, L. M., Grytnes, J. A. and Vandvik, V. (2017). The effect of a mobile application tool on biology students' motivation and achievement in species identification: A self-determination Theory perspective. Computers \& Education, 107(2017):1-12.

[28] Kajogbola, D. O. (2004). The Impact of Information Technology on the Nigerian Economy: A Study of Manufacturing and Services Sectors in the South Western and South Eastern Zones of Nigeria. Nairobi, Kenya: African Technology Policy Studies Network.

[29] Kay, R. H. (2008). Exploring Gender Differences in Computer-Related Behaviour: Past, Present, and Future. In Social Information Technology: Connecting Society and Cultural Issues. pp.12-30 DOI: 10.4018/978-1-59904-774-4.ch002

[30] Kay, R. \& Knaack, L. (2008). Investigating the use of learning objects for secondary school mathematics. Interdisciplinary Journal of E-Learning and Learning Objects, 6:217-238.

[31] Leach, L. \& Turner, S. (2015). Computer Users Do Gender: The Co-Production of Gender and Communications Technology. Sage open (2015):1-14. DOI:10.1177/2158244015604693

[32] Maddaloni, S. (2013). What are Learning Objects? Definition and components. Available at https://www.docebo.com/2013/01/03/what-is-learning-objects-elearning/. Accessed 25 November 2016.

[33] Ndomi, B. M. (2005). Revisiting the Learning Experience of Technical College Farm Machinery curriculum for empowerment of Recipients in Nigeria. Journal of Nigerian association of teachers of technology (JONATT), 5(1):88-94.

[34] Ng'ambi, D., Brown, C., Bozalek, V., Gachago, D. \& Wood, D. (2016). Technology enhanced teaching and learning in South African higher education - A rearview of a 20-year journey: 20 
Using Digital Learning Objects (DLOs) for Students' Achievement in Computer Appreciation Studies

years reflection on technology enhanced learning. British Journal of Educational Technology, 47(5):843-858

[35] Nguen, Q., Rienties, B., Toetenel, L., Ferguson, F. \& Whdelock, D. (2017). Examining the designs of computer-based assessment and it impact on students' engagement, satisfaction and pass rates. Computers in human behavior, 76 (November):703-714. https://doi.org/10.1016/j.chb.2017.03.028

[36] Nwoji, Q. J. 2003. Effective Utilization of human resources for the Teaching of Introducing Technology. The Nigerian Universal Basic Education, 2(1):173-178.

[37] Oguz, S. (2011). Effects of computer based instruction on the achievement and problem solving skills of the science and technology Students. Turkish Online Journal of Educational Technology-TOJET, 10(1):183-201.

[38] Okyumen, M. I. \& Gbodi, E. B. (2015). Impact on E-learning on achievement of technical college students. Journal of Research, Curriculum and Teaching, 2(1):103-111.

[39] Olawojero, C. (2013). Impact of Computer Education on students' interest and performance in automobile trade in Nigerian secondary schools and colleges. Journal of Education and Practice, 4(11):89-95.

[40] Olelewe, C. J. \& Agomuo, E. E. (2016). Effects of B-learning and F2F learning environments on students' achievement in QBASIC programming. Computers \& Education 103(December):76-86.

[41] Osaigbovo, T. (n.d.) Computer Appreciation and Application. Available at https://www.scribd.com/document/42628005/Computer-Appreciation-and-Application. Accessed 17 January 2017.

[42] Page, T. (2014). Skeuomorphism or flat design: Future designs in mobile device user interface (UI) design education. International Journal of mobile learning and organization, 8(2):130142 .

[43] Reyna, J., Meier, P., Geronimo, F. \& Rodgers, K. (2016). Implementing Digital Media Presentations as assessment tools for pharmacology students. American Journal of Educational Research, 4(14):983-991.

[44] Robson, S. (2014). South Africa education gets e-learning digital makeover. Available at https://www.bbc.com/news/business-28191371. Accessed 22 April 2019.

[45] Romero, F. T., Rosa, C. P., Corcoles, Y. R. \& Ponce, A. T. (2015). Effects of Innovative teaching methods on students' academic performance: An empirical study on financial accounting. Junio, 16(2):109-128.

[46] Ryan, R. M. \& Deci, E. L. (2000). Self-determination theory and the facilitation of intrinsic motivation, social development, and well-being. American Psychologist, 55: 68-78. doi:10.1037/0003-066X.55.1.68.

[47] Study.com (2018). What Are Technical Schools? Accessed at https://study.com/technical_schools.html

[48] Tanaka, R. Y., Catalan, V. M., Zemiack, J., Pedro E. N., Cogo, A. L.\& Silveira, D. T. (2010). Digital Learning Objects and assessment tool for the practice of nursing education. Acta Paulista de Enfermgem, 23(5):603-607.

[49] Tebabal, A. \& Kahssay, G. (2011). The effects of student-centered approach in improving students' graphical interpretation skills and conceptual understanding of kinematical motion. Latin-American Journal of Physics Education, 5(2):374-381.

[50] Thoma, R. J., Cook, J. A., Mcgrew, C., King, J. H. K., Pulsipher, D. T., Yep, R. A., Monnig, M. A. Mayer, A., Pommy, J., \& Campbell, R. A. (2018). Convergent and discriminant validity 
of the ImPACT with traditional neuropsychological measures, Cogent Psychology, 5(1). DOI: 10.1080/23311908.2018.1430199

[51] Uzoagulu, A. E. (1998). Towards an effective equipment management (EEM) in schools for Economic and technological self - reliance. Paper presented at the $7^{\text {th }}$ annual Conference of NVA held at FCE (T), Umunze, 20-24 July.

[52] Vidal-Castro, C. (2017). Towards a holistic model for quality of learning object repositories: A practical application to the indicator of metadata compliance. https://doi.org/10.1108/EL10-2015-0202

[53] Wang, Y. (2013). More People have cell phones than toilets. Available at http://newsfeed.time.com/2013/03/25/more-people-have-cell-phones-than-toilets-u-n-studyshows/. Accessed 19 January 2017.

[54] Wentworth, D. K. \& Middleton, J. H. (2014).Technology use and academic performance. Computer \& Education, 78(2014):306-311.

[55] White, H. \& Sabarwal, S. (2014). Quasi-experimental Design and Methods, Methodological Briefs: Impact Evaluation 8. Florence, Italy: UNICEF Office of Research.

[56] Wiley, D. A. (2002). Connecting Learning Objects to Instructional Design Theory: A Definition, a Metaphor, and a Taxonomy. The Instructional Use of Learning Objects. Bloomington, IN: Agency for Instructional Technology. Available at http://reusability.org/read/chapters/wiley.doc. Accessed 25 November 2016.

[57] World Economic Forum (2013). Deep shift Technology Tipping Points and Societal Impact. Available at http://www3.weforum.org/docs/WEF_GAC15_Technological_Tipping_Points_report_2015.p df. Accessed 19 January 2017.

[58] Zimudzi, E. (2012). Web-based learning objects for senior school computer studies. Asian journal of management sciences and education, 1(1):52-62. 